\title{
Assembly of a Dihydrideborate and two Aryl Nitriles to Form a C,N,N'-Pincer Ligand Coordinated to Osmium
}

\author{
Juan C. Babón, ${ }^{\dagger}$ Miguel A. Esteruelas, , Israel Fernández, ${ }^{*}$ Ana M. López, ${ }^{\dagger}$ and Enrique Oñate ${ }^{+}$ \\ †Departamento de Química Inorgánica, Instituto de Síntesis Química y Catálisis Homogénea (ISQCH), Centro de Innovación en \\ Química Avanzada (ORFEO-CINQA), Universidad de Zaragoza-CSIC, 50009 Zaragoza, Spain. \\ ‡Departamento de Química Orgánica I, Facultad de Ciencias Químicas, Centro de Innovación en Química Avanzada (ORFEO- \\ CINQA), Universidad Complutense de Madrid, 28040 Madrid, Spain.
}

\begin{abstract}
The C,N,N'-donor aryl-diimineborate pincer ligand of complexes $\mathrm{OsH}_{2}\left\{\kappa^{3}-C, N, N-\right.$ $\left.\left[\mathrm{C}_{6} \mathrm{H}_{3} \mathrm{RCH}=\mathrm{NB}(\mathrm{cat}) \mathrm{N}=\mathrm{CHC}_{6} \mathrm{H}_{4} \mathrm{R}\right]\right\}\left(\mathrm{P}^{\mathrm{i}} \mathrm{Pr}_{3}\right)_{2}(\mathrm{R}=\mathrm{H}, \mathrm{Me})$ has been generated in a one-pot procedure, by the reaction of the hexahydride $\mathrm{OsH}_{6}\left(\mathrm{P}^{\mathrm{i}} \mathrm{Pr}_{3}\right)_{2}$ with catecholborane (catBH) and two molecules of the corresponding aryl nitrile. The osmium-pincer bonding situation has been analyzed by means of Atoms In Molecules (AIM), Natural Bond Orbital (NBO), and Energy Decomposition Analysis coupled with the Natural Orbitals for Chemical Valence (EDA-NOCV) methods. According to the results, it exhibits a rather strong electron-sharing Os-C bond, two weaker donor-acceptor $\mathrm{N}$-to-Os bonds, and two $\pi$-backdonations from the transition metal to vacant $\pi^{*}$ orbitals of the formed metallacycles. In addition, spectroscopic findings and DFT calculations reveal that the donor units of the pincer are incorporated in a sequential manner. Firstly, the central Os- $\mathrm{N}$ bond is formed, by the reaction of the dihydrideborate ligand of intermediate $\mathrm{OsH}_{3}\left\{\kappa^{2}-H, H-\right.$ $\left.\left(\mathrm{H}_{2} \mathrm{Bcat}\right)\right\}\left(\mathrm{P}^{\mathrm{i}} \mathrm{Pr}_{3}\right)_{2}$ with one of the aryl nitriles. The subsequent oxidative addition of the ortho-C-H bond of the aryl substituent of the resulting $\kappa^{1}-N$-(N-boryl-arylaldimine) affords the Os-C bond. Lastly, the second Os- $\mathrm{N}$ bond is generated from a hydride, an orthometalated $\mathrm{N}$ boryl-arylaldimine and the second aryl nitrile.
\end{abstract}

\section{INTRODUCTION}

Transition metal complexes stabilized by pincer ligands are having a great impact on modern chemistry because of their high stability and the broad range of their applications, ${ }^{1}$ which extend from catalysis $^{2}$ and medicine ${ }^{3}$ to materials science. ${ }^{4}$ Thus, platinum group metal pincer complexes are currently situated at the forefront of important fields such as homogeneous catalysis ${ }^{5}$ or photophysics. ${ }^{6}$ Furthermore, the disposition of their donor atoms at the metal coordination sphere allows them to develop a noticeable ability to form uncommon coordination polyhedra and favor unusual metal oxidation states. As a consequence, rare compounds have been recently discovered, as for instance the mer-tris(boryl) derivative $\operatorname{Ir}(\text { Bcat })_{3}\left\{\boldsymbol{\kappa}^{3}\right.$-P,O,P- $\left.\left[\operatorname{xant}\left(\mathrm{P}^{\mathrm{i}} \mathrm{Pr}_{2}\right)_{2}\right]\right\} \quad\left(\operatorname{xant}\left(\mathrm{P}^{\mathrm{i}} \mathrm{Pr}_{2}\right)_{2}=\right.$ 9,9-dimethyl4,5-bis(diisoproylphosphino)xanthene), which challenges the concept of trans influence, ${ }^{7}$ or families of metallapentalenes, hetero-metallapentalenes, ${ }^{8}$ and metallapentalynes, ${ }^{9}$ with planar Möbius aromaticity.

Osmapentalenes and osmapentalynes are known. ${ }^{8,9}$ However, pincer complexes of this element are scarce in comparison with the number of known compounds for the rest of platinum group metals. The pincer ligands coordinated to this element mainly involve neutral $^{10}$ or monoanionic ${ }^{10 f, 11}$ moieties, which result from the simple coordination of tridentate molecules ${ }^{10}$ or the coordination of bidentate groups along with the $\sigma$-bond activation of one of their substituents, ${ }^{11}$ whereas osmium complexes bearing dianionic pincer ligands are very rare. Examples include $\mathrm{C}, \mathrm{C}^{\prime}, \mathrm{N}$-donors, which are generated by coordination of a $2 \mathrm{e}$-donor $\mathrm{N}$ atom and two $\sigma$-bond activations at the molecule skeleton, ${ }^{12}$ or $\mathrm{O}, \mathrm{N}, \mathrm{O}-{ }^{13}{ }^{13} \mathrm{C}, \mathrm{C}, \mathrm{C}-{ }^{14}$ and
$\mathrm{C}, \mathrm{N}, \mathrm{C}$-donors, ${ }^{15}$ which are formed as a consequence of the coordination of a $2 \mathrm{e}$-donor atom and a $\sigma$-bond activation at two substituents of the molecular core. ${ }^{13-15}$

This paper describes the discovery of a new class of formally dianionic pincer ligands coordinated to osmium, aryl-diimineborate $\left(\mathrm{C}, \mathrm{N}, \mathrm{N}^{\prime}\right)$, which are furthermore generated on the metal coordination sphere by a novel procedure involving the coupling of a coordinated dihydrideborate anion with two aryl nitrile molecules and the activation of an ortho- $\mathrm{CH}$ bond of the aryl group of one of them.

\section{RESULTS AND DISCUSSION}

Isolation and Characterization of the Complexes. The discovery was completely accidental. We were studying the reactions of the hexahydride complex $\mathrm{OsH}_{6}\left(\mathrm{P}^{\mathrm{i}} \mathrm{Pr}_{3}\right)_{2}(1)$ with boranes ${ }^{16}$ and nitriles ${ }^{17}$ as a part of our work on the chemistry of polyhydride complexes of platinum group metals ${ }^{18}$ and we observed that while complex 1 promoted the catalytic addition of the $\mathrm{B}-\mathrm{H}$ bond of catecholborane (catBH) and pinacolborane (pinBH) to alkyl nitriles to give borylimines, which under the reaction conditions evolved to diborylamines, ${ }^{19}$ it was inactive for the same reactions with aryl nitriles. The finding did not surprise us since we had noticed a similar effect of the aryl groups on the reactions of hydrogenation of these substrates to secondary amines. In that case, the intermediate arylaldimine reacted with 1 to give the catalytically unproductive trihydrides $\mathrm{OsH}_{3}\left\{\kappa^{2}-C, N-\left(\mathrm{C}_{6} \mathrm{H}_{3} \mathrm{RCH}=\mathrm{NH}\right)\right\}\left(\mathrm{P}^{\mathrm{i}} \mathrm{Pr}_{3}\right)_{2}(\mathrm{R}=\mathrm{H}, \mathrm{Me})$, as a result of the coordination of the nitrogen atom and the activation of an ortho- $\mathrm{CH}$ bond of the aryl substituent. ${ }^{17 \mathrm{~b}}$ To check the 
formation of a similar compound resulting from an analogous reaction with a $\mathrm{N}$-boryl-arylaldimine, we treated complex 1 with 5 equiv of benzonitrile and 10 equiv of catBH, in toluene, at $50{ }^{\circ} \mathrm{C}$, for $6 \mathrm{~h}$. To our surprise, the formed species was the dihydridepincer derivative $\mathrm{OsH}_{2}\left\{\kappa^{3}-C, N, N\right.$ $\left[\mathrm{C}_{6} \mathrm{H}_{4} \mathrm{CH}=\mathrm{NB}\right.$ (cat)N=CHPh $\left.]\right\}\left(\mathrm{P}^{\mathrm{i}} \mathrm{Pr}_{3}\right)_{2}(2)$, which was isolated as a 85:15 mixture of the isomers $\mathbf{a}$ and $\mathbf{b}$ shown in Scheme 1. Similarly, the reaction with $o$-tolunitrile afforded the methyl-substituted analog $\mathrm{OsH}_{2}\left\{\kappa^{3}-\right.$ $C, N, N\left[\mathrm{C}_{6} \mathrm{H}_{3} \mathrm{MeCH}=\mathrm{NB}(\right.$ cat $\left.\left.) \mathrm{N}=\mathrm{CHC}_{6} \mathrm{H}_{4} \mathrm{Me}\right]\right\}\left(\mathrm{P}^{\mathrm{i}} \mathrm{Pr}_{3}\right)_{2} \quad$ (3), as only one isomer. The methyl group increases the steric hindrance of the aryl substituent of the pincer and this appears to destabilize isomer $\mathbf{b}$ with respect to $\mathbf{a}$.

Scheme 1. Reactions of Complex 1 with Aryl Nitriles and Catecholborane

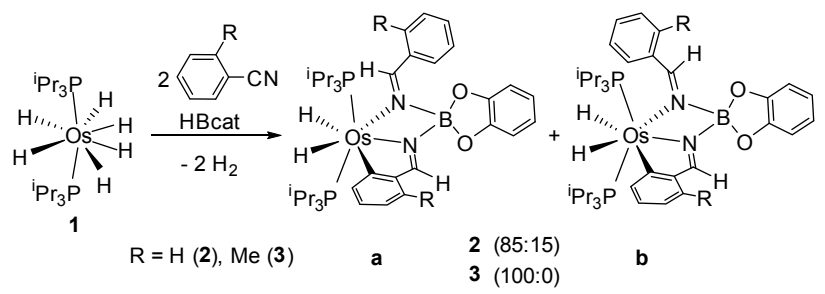

Orange crystals of 2a suitable for X-ray diffraction analysis were obtained at $-30^{\circ} \mathrm{C}$ from a pentane solution. The structure, which has two molecules chemically equivalent but crystallographically independent in the asymmetric unit (Figure 1 shows one of them), proves the formation of the pincer. The tridentate ligand acts with $\mathrm{N}(2)-$-Os-N(1), N(1)-Os-C(1), and $\mathrm{N}(2)-\mathrm{Os}-\mathrm{C}(1)$ angles of 67.2(4) and 66.8(3) $)^{\circ}, 75.2(4)$ and 75.6(4) , and 142.3(4) in both molecules, respectively. The angle $\mathrm{N}(2)-\mathrm{Os}-\mathrm{C}(1)$ is particularly noticeable. It is very close to the ideal value of $144^{\circ}$ for a pentagonal-bipyramidal arrangement of donor atoms around the metal center, pointing out that these aryl-diimineborate pincer ligands should be especially useful to stabilize complexes of $\mathrm{d}^{4}$-ions with a pentagonal-bipyramidal structure, ${ }^{15 a, 20}$ which is also the observed one in 2 . The phosphines in the apical positions $(\mathrm{P}(1)-\mathrm{Os}-\mathrm{P}(2)=$ $159.48(10)$ and $\left.160.93(10)^{\circ}\right)$ and the hydrides, separated by 1.9(1) and 1.7(1) $\AA$, in the pincer plane complete its coordination polyhedron. In agreement with the presence of two inequivalent hydride ligands, the ${ }^{1} \mathrm{H}$ NMR spectra of 2 and 3 in benzene- $d_{6}$ show two doublets $\left({ }^{2} \mathrm{H}_{\mathrm{H}-\mathrm{H}} \approx 21 \mathrm{~Hz}\right)$ of triplets $\left({ }^{2} \mathrm{H}-\mathrm{P} \approx 14 \mathrm{~Hz}\right)$ at about -4.5 and $-7.5 \mathrm{ppm}$. In the ${ }^{31} \mathrm{P}\left\{{ }^{1} \mathrm{H}\right\}$ NMR spectra, the equivalent phosphines give rise to a singlet at $6.4 \mathrm{ppm}$ for both compounds. The ${ }^{13} \mathrm{C}\left\{{ }^{1} \mathrm{H}\right\}$ NMR spectra contain a triplet $\left({ }^{2} / \mathrm{C}-\mathrm{P}=6 \mathrm{~Hz}\right)$ corresponding to the metalated carbon atom of the pincer, between 166 and $164 \mathrm{ppm}$. A broad signal centered at $14.8 \mathrm{ppm}$ in the ${ }^{11} \mathrm{~B}$ NMR spectra, due to the catB linker, is also a characteristic of these borates.

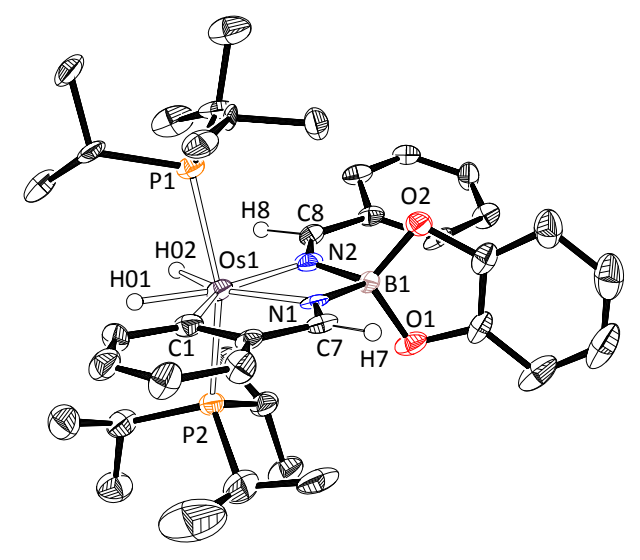

Figure 1. Molecular structure of one of the two independent molecules of complex $2 \mathrm{a}$ (50\% probability ellipsoids) in the asymmetric unit. Hydrogen atoms except for hydrides and those attached to $\mathrm{C}_{\alpha}$ atoms of the imine groups are omitted for clarity. Selected bond distances $(\AA)$ and angles (deg): $\mathrm{Os}(1)-\mathrm{C}(1)=2.076(12), 2.074(11), \mathrm{Os}(1)-\mathrm{N}(1)=$ 2.045(9), 2.021(9), Os(1)-N(2) = 2.137(9), 2.142(10), N(1)-C(7) $=1.263(14), 1.281(14), \mathrm{N}(1)-\mathrm{B}(1)=1.556(17), \quad 1.558(14)$, $\mathrm{N}(2)-\mathrm{C}(8)=1.282(14), 1.288(14), \mathrm{N}(2)-\mathrm{B}(1)=1.561(16)$, $1.582(15) ; \mathrm{N}(2)-\mathrm{Os}(1)-\mathrm{N}(1)=67.2(4), 66.8(3), \mathrm{N}(1)-\mathrm{Os}(1)-\mathrm{C}(1)=$ 75.2(4), 75.6(4), N(2)-Os(1)-C(1) = 142.3(4), 142.3(4), $\mathrm{P}(1)-$ Os(1)-P(2) = 159.48(10), 160.93(10).

The novelty of this class of pincer ligands prompted us to study their interactions with the metal center. The osmium-pincer bonding situation was analyzed by means of DFT calculations (BP86D3/def2-SVP) initially using Atoms In Molecules (AIM) and Natural Bond Orbital (NBO) methods. The AIM method displays the expected Os-C and Os-N bond critical points (BCPs) together with their associated bond paths (BPs) running between these atoms and two additional ring critical points associated with the five- $\left(\mathrm{OsNC}_{3}\right)$ and four-membered $\left(\mathrm{OsN}_{2} \mathrm{~B}\right)$ rings (Figure 2). Although in all cases the Laplacian distribution in the Os-N-B-N plane exhibits the shape of a droplet-like directed towards the osmium atom, typical for a donor-acceptor interaction, ${ }^{21}$ the computed delocalization index, $\delta$, which is a measure of the relative bond strength, ${ }^{22}$ indicates that the Os-C bond $(\delta=0.89)$ is significantly stronger than both Os-N bonds $(\delta=0.65$ and 0.71$)$. A similar result is found by applying the NBO method. The computed Wiberg bond index (WBI) for the Os-C bond (0.67) is markedly higher than the values computed for the Os-N bonds (WBI = 0.40 and 0.42 , respectively).

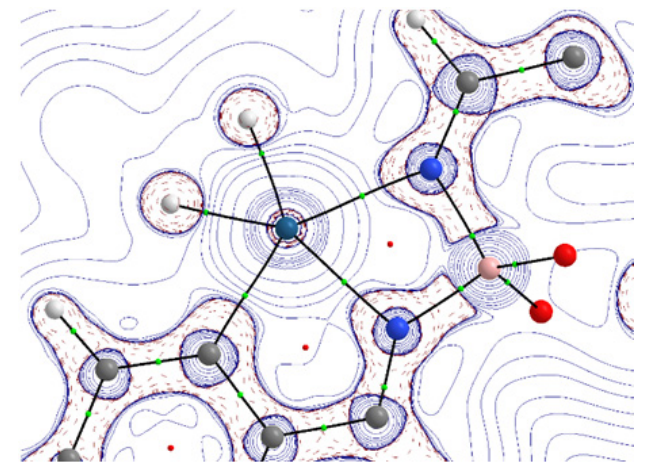

Figure 2. Contour line diagrams $\nabla^{2} \rho(\mathrm{r})$ for complex 2a in the Os-N$\mathrm{B}-\mathrm{N}$ plane. The solid lines connecting the atomic nuclei are the bond paths while the small green and red spheres indicate the corresponding 
bond critical points and ring critical points, respectively. [Legend: $\mathrm{H}$ (white), B (pink), C (gray), Os (dark blue) and N (light blue)].

The osmium-pincer bonding situation could be described in terms of two donor-acceptor $\mathrm{N}$-to-Os bonds and an electronsharing Os-C bond, according to the AIM and NBO results. Figure 3 depicts the main orbital interactions, computed using the Energy Decomposition Analysis coupled with the Natural Orbitals for Chemical Valence method (EDA-NOCV). As clearly seen, the strength of both donor-acceptor N-to-Os bonds is rather similar (34.2 and $-22.0 \mathrm{kcal} \mathrm{mol}^{-1}$ ) and significantly weaker than the electron-sharing Os-C bond $\left(-136.7 \mathrm{kcal} \mathrm{mol}^{-1}\right)$. This agrees with the relative bond strengths suggested by the computed delocalization and Wiberg bond indices. Moreover, the NOCV method identifies two additional $\pi$-backdonations from the transition metal fragment to vacant $\pi^{*}(\mathrm{C}=\mathrm{C})$ and $\pi^{*}(\mathrm{C}=\mathrm{N})$ orbitals of the metallacycles. These $\pi$-backdonations, which resemble those found in related fused-ring osmacycles, ${ }^{23}$ have a similar strength to the donoracceptor N-to-Os bonds ( -24.2 and $-18.3 \mathrm{kcal} \mathrm{mol}^{-1}$, respectively). Therefore, the metal-pincer interaction in $2 \mathrm{a}$ exhibits a rather strong electron-sharing Os-C bond, two weaker donor-acceptor $\mathrm{N}$-to-Os bonds and two $\pi$-backdonations from the transition metal fragment to vacant $\pi^{*}$ orbitals of the formed metallacycles.
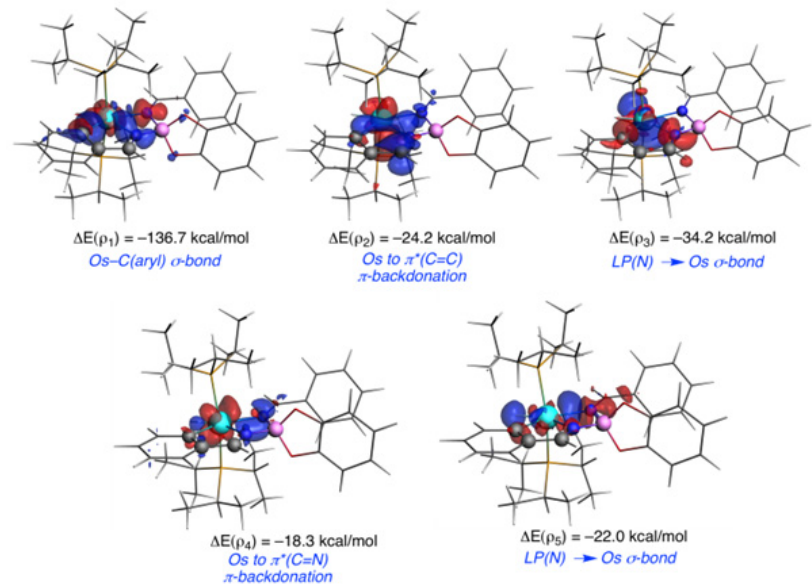

Figure 3. NOCV-deformation densities and associated stabilization energies computed for complex $2 \mathrm{a}$. The charge flow takes place in the direction red $\rightarrow$ blue.

Mechanism of the Formation of the Pincer. Complex 1 individually reacts with both catBH and benzonitrile. The reaction with catBH affords the trihydride-dihydrideborate $\mathrm{OsH}_{3}\left\{\kappa^{2}-H, H\right.$ $\left.\left(\mathrm{H}_{2} \mathrm{Bcat}\right)\right\}\left(\mathrm{P}^{\mathrm{i}} \mathrm{Pr}_{3}\right)_{2}(4),{ }^{16}$ whereas the reaction with benzonitrile gives the trihydride-azavinylidene $\mathrm{OsH}_{3}(=\mathrm{N}=\mathrm{CHPh})\left(\mathrm{P}^{\mathrm{i}} \mathrm{Pr}_{3}\right)_{2}$ (5).$^{17 \mathrm{~b}}$ So, in principle, either of the compounds could be the precursor of 2 . In the search for understanding the formation of the pincer ligand, we followed the reaction of 1 with HBcat and benzonitrile by ${ }^{31} \mathrm{P}\left\{{ }^{1} \mathrm{H}\right\}$ NMR spectroscopy, as a function of time (Figure 4). The spectra show the initial formation of the trihydridedihydrideborate 4 , which is transformed into the isomeric mixture of $2 a$ and $2 b$, via two unknown species 6 and 7 . No traces of the azavinylidene 5 were detected. This is consistent with previous DFT calculations suggesting that the activation barrier for the formation of $\mathbf{4}$ is significantly lower than that for the formation of 5. ${ }^{176,19}$ To confirm the participation of complex 4 in the formation of 2 , we added 1.0 equiv of benzonitrile to a toluene solution of this complex contained in a NMR tube, at $-78^{\circ} \mathrm{C}$. As expected, the quantitative formation of 6 took place. It decomposes to an illdefined mixture, at room temperature. However, in the presence of 4 equiv of benzonitrile, complex 6 evolves into 2, via 7 detected in the ${ }^{31} \mathrm{P}\left\{{ }^{1} \mathrm{H}\right\}$ NMR spectra $\left(\delta^{31} \mathrm{p}, 26.0\right)$.

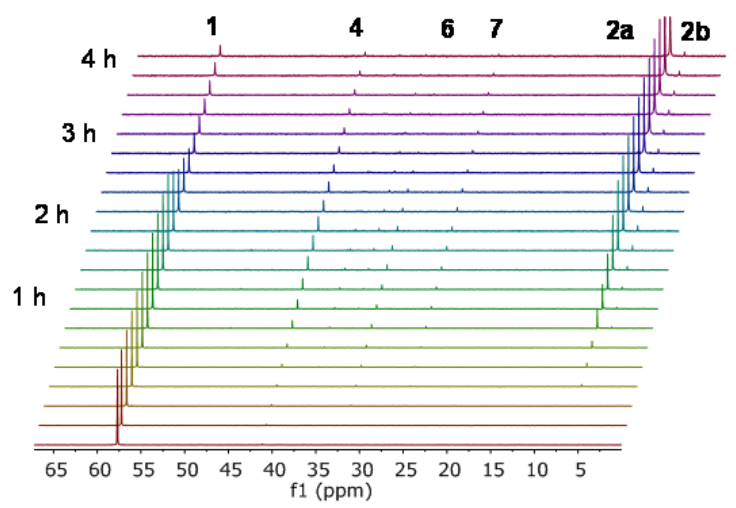

Figure 4. ${ }^{31} \mathrm{P}\left\{{ }^{1} \mathrm{H}\right\}$ NMR spectra of the reaction of $1(0.1 \mathrm{M})$ with benzonitrile $(0.5 \mathrm{M})$ and catecholborane $(1.0 \mathrm{M})(1: 5: 10$ molar ratio) in toluene- $d_{s}$ at $50{ }^{\circ} \mathrm{C}$ as a function of time. Spectra were recorded at regular intervals of $12 \mathrm{~min}$ during $4 \mathrm{~h}$.

The ${ }^{11} \mathrm{~B},{ }^{1} \mathrm{H}$, and ${ }^{13} \mathrm{C}\left\{{ }^{1} \mathrm{H}\right\}$ spectra of 6 strongly support the presence of an imine-hydrideborate anion coordinated to the metal center. Thus, the first spectrum contains a broad signal centered to $-6.7 \mathrm{ppm}$; the second one shows a downfield imine resonance at $9.08 \mathrm{ppm}$, coupled in ${ }^{1} \mathrm{H}-{ }^{13} \mathrm{C}$ HSQC to ${ }^{13} \mathrm{C}$ NMR signal at 156.3 ppm, along with a $\mathrm{HB}$ resonance at $-4.97 \mathrm{ppm}$. The ${ }^{1} \mathrm{H}$ NMR spectrum at $183 \mathrm{~K}$ also reveals the presence of three inequivalent hydrides in the coordination plane of the borate, with three signals at 8.86, -10.62 , and $-10.80 \mathrm{ppm}$, whereas the ${ }^{31} \mathrm{P}\left\{{ }^{1} \mathrm{H}\right\}$ NMR spectrum displays a singlet at $30.5 \mathrm{ppm}$ consistent with equivalent phosphine ligands. According to these spectroscopic features, intermediate 6 is the osmium(IV) species $\mathrm{OsH}_{3}\left\{\kappa^{2}-H, N\right.$ $[\mathrm{HB}(\mathrm{cat}) \mathrm{N}=\mathrm{CHPh}]\}\left(\mathrm{P}^{\mathrm{i}} \mathrm{Pr}_{3}\right)_{2}$, resulting from the insertion of the $\mathrm{N}-\mathrm{C}$ triple bond of the nitrile in one of the B-H bonds of the dihydrideborate of 4 .

Complexes bearing imine-hydrideborate ligands are known but scarce. Milstein and co-workers have reported that the reaction of $\mathrm{FeBr}_{2}$ with 4,5-bis(diphenylphosphino)acridine ( $\left.{ }^{\mathrm{HACR}} \mathrm{PNP}\right)$ in an acetonitrile solution containing 2 equiv of $\mathrm{NaBH}_{4}$ gives $\mathrm{Fe}\left\{\kappa^{2}-H, N\right.$ $\left.\left[\mathrm{H}-\mathrm{BH}_{2}-\mathrm{N}=\mathrm{CHMe}\right]\right\}(\mathrm{MeC} \equiv \mathrm{N})\left\{\kappa^{3}-P, N, P\right.$ - $\left.\left.{ }^{\mathrm{HACR}} \mathrm{PNP}\right)\right\},{ }^{24}$ whereas Berke and co-workers have prepared the rhenium complex $\operatorname{Re}\left\{\kappa^{2}\right.$ $\left.H, N-\left[\mathrm{H}-\mathrm{BH}_{2}-\mathrm{N}=\mathrm{CHMe}\right]\right\} \mathrm{Cl}\left(\mathrm{PMe}_{3}\right)_{2}(\mathrm{NO})$ by addition of $\left[\mathrm{BH}_{4}\right]$ to the acetonitrile precursor $\mathrm{ReCl}_{2}(\mathrm{MeC} \equiv \mathrm{N})\left(\mathrm{PMe}_{3}\right)_{2}(\mathrm{NO}){ }^{25}$ Nikonov's group has observed that the addition of catBH to the azavinylidene-molybdenum compound $\mathrm{Mo}(=\mathrm{N}-2,6-$ $\left.{ }^{\mathrm{i}} \mathrm{Pr}_{2} \mathrm{C}_{6} \mathrm{H}_{3}\right)(=\mathrm{N}=\mathrm{CHPh}) \mathrm{Cl}\left(\mathrm{PMe}_{3}\right)_{2} \quad$ affords $\mathrm{Mo}\left\{\kappa^{2}-H, N\right.$ $[\mathrm{HB}(\mathrm{cat}) \mathrm{N}=\mathrm{CHPh}]\}\left(=\mathrm{N}-2,6-{ }^{-} \mathrm{Pr}_{2} \mathrm{C}_{6} \mathrm{H}_{3}\right) \mathrm{Cl}\left(\mathrm{PMe}_{3}\right)_{2}$, bearing the same imine-hydrideborate as $6 .^{26}$

Intermediate 7 is most probably the orthometalated borylaldimine derivative $\mathrm{OsH}_{3}\left\{\kappa^{2}-N, C\right.$ - $\left[\mathrm{N}(\right.$ Bcat $\left.\left.)=\mathrm{CHC}_{6} \mathrm{H}_{4}\right]\right\}\left(\mathrm{P}^{\mathrm{i}} \mathrm{Pr}_{3}\right)_{2}$, according to the chemical shift of its associated signal in the ${ }^{31} \mathrm{P}\left\{{ }^{1} \mathrm{H}\right\}$ NMR spectra of Figure 4, which resembles that reported for the pinacolborane counterpart $\mathrm{OsH}_{3}\left\{\kappa^{2}-N, C\right.$ $\left[\mathrm{N}(\right.$ Bpin $\left.\left.)=\mathrm{CHC}_{6} \mathrm{H}_{4}\right]\right\}\left(\mathrm{P}^{\mathrm{i}} \operatorname{Pr}_{3}\right)_{2}\left(\delta^{31}{ }_{\mathrm{p}}, 26.0\right) .{ }^{1 \mathrm{bb}}$ Its formation should be the result of the release of a hydrogen molecule from 6 and the ortho- $\mathrm{CH}$ bond activation of the phenyl substituent of the imine 
moiety, in agreement with the marked ability of the osmiumpolyhydrides to activate $\mathrm{C}-\mathrm{H}$ bonds. ${ }^{18}$

Once the sequence of key intermediates for the arrangement of the pincer had been experimentally established, we decided to analyze the formation of 6 and 7 starting from 4 and the transformation of 7 into 2 . To gain information on the intimate details of the processes, we carried out DFT calculations at the dispersioncorrected PCM(toluene)-B3LYP-D3/def2-SVP level (see computational details in the Supporting Information). The changes in free energy $(\Delta G)$ were calculated in toluene at $298.15 \mathrm{~K}$ and $1 \mathrm{~atm}$. Figure 5 shows the computed energy profile, which displays activation energies lower than $22.0 \mathrm{kcal} \mathrm{mol}^{-1}$ with respect to the origin, whereas Scheme 2 gathers all the intermediates involved in the reaction.

The formation of the pincer can be split into three stages, involving each of them the elemental steps for the formation of the respective donor units. The first stage corresponds to the formation of the central Os- $\mathrm{N}$ bond and its elemental steps allow rationalizing the isolation of 6 , which is not a productive intermediate in the formation of the pincer but a side species. During the second stage the Os-C bond is generated and ends up in 7 . The third stage involves the steps leading to the other Os- $\mathrm{N}$ bond and shows the transformation of 7 into the pincer complex.

The first stage begins with the activation of the precursor 4 . This trihydride-dihydrideborate complex is saturated and therefore its reaction with the nitrile requires the previous creation of a coordination vacancy. It occurs by dissociation of a hydrogen molecule through the Kubas type dihydrogen $\left(d_{\mathrm{H}-\mathrm{H}}=0.900 \AA\right)^{18} \sigma$-borane $\left(d_{\mathrm{B}-\mathrm{H}}=1.339 \AA\right)^{16}$ intermediate $\mathrm{A}$. The dissociation leads to $\mathbf{B}$, producing a destabilization of $12.3 \mathrm{kcal} \mathrm{mol}^{-1}$ with respect to 4 . As expected, the subsequent coordination of the nitrile is an exergonic process, which produces a stabilization of $9.8 \mathrm{kcal} \mathrm{mol}^{-1}$. So, the resulting six-coordinate intermediate $\mathrm{C}$ is only $2.5 \mathrm{kcal} \mathrm{mol}^{-1}$ less stable than 4. It evolves by means of the insertion of the $\mathrm{C}-\mathrm{N}$ triple bond of the nitrile into the Os-B bond of the Os- $\sigma$-borane. The insertion, which is consistent with the nucleophilicity of the nitrogen atom and the electrophilicity of the carbon atom of the nitrile, ${ }^{27}$ has to overcome an activation energy of $19.3 \mathrm{kcal} \mathrm{mol}^{-1}$. The boryl migration initially affords $\mathrm{D}$, which evolves into the trihydrideosmium(IV)-(N-boryl-osmaazacyclopropene) intermediate E, by rupture of the boryl-hydride interaction. Intermediate $\mathrm{E}$ is $10.1 \mathrm{kcal}$ mol $^{-1}$ more stable than 4 minus $\mathrm{H}_{2}$ plus benzonitrile. The following step is a 1,2-hydride displacement from the metal center to the carbon atom of the three-membered heterometallaring. The barrier for this shift $\left(16.7 \mathrm{kcal} \mathrm{mol}^{-1}\right)$ is $2.6 \mathrm{kcal} \mathrm{mol}^{-1}$ lower than that computed for the migration of the boryl group to the nitrogen atom of the nitrile. Because the process leads to a $\eta^{2}$-borylimine intermediate $\mathrm{F}$, with the metal center in oxidation state +2 , it can be viewed as a reductive elimination reaction. Once $\mathbf{F}$ is formed, the metal center undergoes a slippage from the coordinated $\mathrm{C}-\mathrm{N}$ double bond to the nitrogen atom to afford the $\kappa^{1}-\mathrm{N}$ isomer $\mathrm{G}$. The latter is only $0.3 \mathrm{kcal} \mathrm{mol}^{-1}$ less stable than the osmium(IV) precursor E. The oxidative addition of the hydrogen molecule, released in the activation process of 4 , to the metal center of $\mathrm{G}$ directly yields 6 , which is $20.9 \mathrm{kcal} \mathrm{mol}^{-1}$ more stable than 4 plus benzonitrile.

The unsaturated metal center of intermediate $\mathrm{G}$ can alternatively undergo the oxidative addition of an ortho- $\mathrm{C}-\mathrm{H}$ bond of the phenyl substituent of the borylimine. The reaction takes place via the Os$(\sigma-\mathrm{CH})$ intermediate $\mathrm{H}$, which lies $6.2 \mathrm{kcal} \mathrm{mol}^{-1}$ above $\mathrm{G}$. It leads to 7 , which is $5.4 \mathrm{kcal} \mathrm{mol}^{-1}$ less stable than 6 . The higher stability of 6 with regard to 7 explains why is possible to isolate 6 at $-78{ }^{\circ} \mathrm{C}$, when 4 reacts with 1.0 equiv of nitrile, while the small difference of stability between them is consistent with the observation of both, at $50{ }^{\circ} \mathrm{C}$, during the course of the pincer formation. Complex 7 is a true key intermediate in the formation of the pincer, in contrast to 6. This is because its boron atom displays a significant increase of electrophilicity with respect to that of the boron atom of catBH and 6. As a proof-of-concept of this finding, it should be pointed that the computed positive charge on this atom in the sequence catBH, 6 , and 7 increases in the following manner: $+0.96<+1.07<+1.34$. As a consequence of this increased electrophilicity, the boron atom of 7 is able to undergo the nucleophilic attack of a second benzonitrile molecule. The resulting adduct I allows one of the hydride ligands to approach the $\mathrm{C}(\mathrm{sp})$ atom of the nitrile, which permits

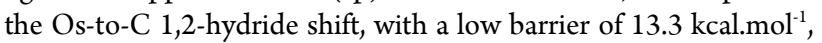
and therefore the formation of the pincer of $2 \mathrm{a}$ in an overall exergonic process by $36.2 \mathrm{kcal} \mathrm{mol}^{-1}$.

The presence of a small amount of $\mathbf{2 b}$ in the reaction mixtures shown in Figure 4 suggests an accessible activation barrier, under the reaction conditions, for the rotation of the $\mathrm{CHPh}$ moiety of the pincer ligand around the exocyclic $\mathrm{C}-\mathrm{N}$ double bond. 


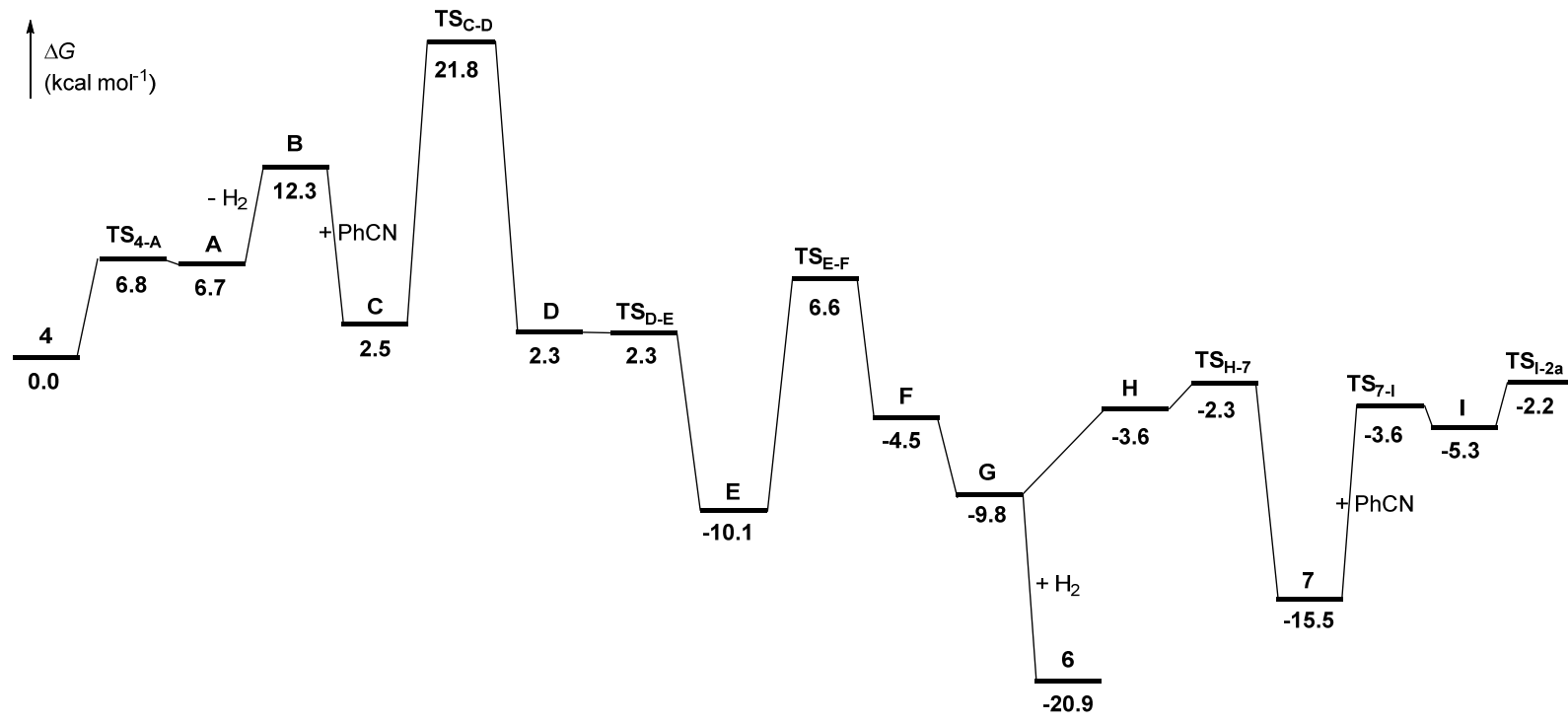

Figure 5. DFT-computed energy profile for the formation of complex 2a

Scheme 2. Intermediates for the Formation of Complex $2 a$ (isolated or detected species are in a red box)

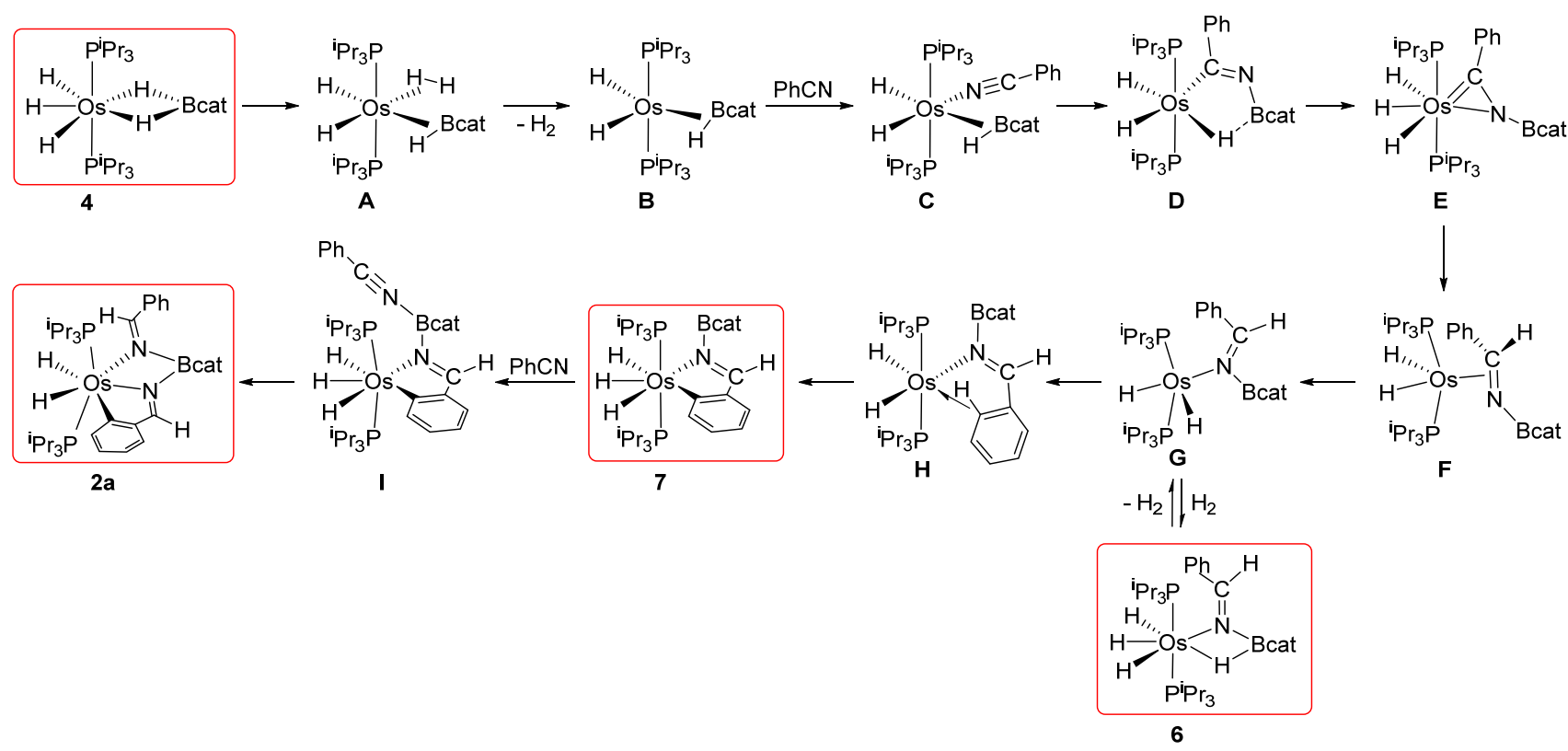

\section{CONCLUDING REMARKS}

This study shows the discovery of a new class of pincer ligands, $\mathrm{C}, \mathrm{N}, \mathrm{N}^{\prime}$-donor aryl-diimineborate, which is particularly appropriate to stabilize pentagonal-bipyramidal structures. The osmium-pincer bonding situation includes a rather strong electron-sharing Os-C bond, two weaker donor-acceptor $\mathrm{N}$-to-Os bonds and two $\pi$ backdonations from the metal fragment to vacant $\pi^{*}$ orbitals of the formed metallacycles. The pincer ligands have been generated on the metal coordination sphere of an osmium(IV) center from a dihydrideborate ligand and two aryl nitriles. Spectroscopic findings and DFT calculations have revealed that the formation of the donor units of the pincer is a sequential process, which takes place in three stages. The first of them involves the formation of the central Os-N bond, by the reaction of the dihydrideborate ligand and an external aryl nitrile. During the second one, the Os- $\mathrm{C}$ bond is generated by oxidative addition of the ortho- $\mathrm{C}-\mathrm{H}$ bond of the aryl substituent of a $\kappa^{1}-N$-(N-boryl-arylaldimine) ligand. The third stage, which is initiated by the nucleophilic attack of a second aryl nitrile to the boron atom of the resulting orthometalated N-boryl-arylaldimine, gives rise to the Os-N' bond. 
In summary, a novel class of pincer ligands has been generated on the coordination sphere of an osmium(IV) metal center, in a onepot-procedure, by the assembly of catecholborane and two aryl nitriles and the corresponding formation mechanism has been established based on spectroscopic observations and DFT calculations.

\section{EXPERIMENTAL SECTION}

All manipulations were performed with rigorous exclusion of air at an argon/vacuum manifold using standard Schlenk-tube or glovebox techniques. Solvents were dried by the usual procedures and distilled under argon prior to use or obtained oxygen- and water-free from an MBraun solvent purification apparatus. Pentane was stored over $\mathrm{P}_{2} \mathrm{O}_{5}$ in the glovebox. Toluene was stored over sodium in the glovebox. Complex $\mathrm{OsH}_{6}\left(\mathrm{Pirr}_{3}\right)_{2}(1)^{28}$ was prepared according to the published methods. Instrumentation for characterization, $\mathrm{X}$-ray information, and computational details are given in the Supporting Information. Chemical shifts (in parts per million) in the NMR spectra are referenced to residual solvent peaks $\left({ }^{1} \mathrm{H},{ }^{13} \mathrm{C}\left\{{ }^{1} \mathrm{H}\right\}\right)$, external $\mathrm{H}_{3} \mathrm{PO}_{4}\left({ }^{31} \mathrm{P}\left\{{ }^{1} \mathrm{H}\right\}\right)$, or $\mathrm{BF}_{3} \cdot \mathrm{OEt}_{2}\left({ }^{11} \mathrm{~B}\left\{{ }^{1} \mathrm{H}\right\}\right)$. Coupling constants, $J$, and $N\left(N={ }^{3} J_{\mathrm{H}-\mathrm{P}}+{ }^{5} J_{\mathrm{H}-\mathrm{P}^{\prime}}\right.$ for ${ }^{1} \mathrm{H}$ or ${ }^{1} J_{\mathrm{C}-\mathrm{P}}+{ }^{3} J_{\mathrm{C}-\mathrm{P}^{\prime}}$ for $\left.{ }^{13} \mathrm{C}\right)$ are given in hertz.

Preparation of $\mathrm{OsH}_{2}\left\{\boldsymbol{x}^{3}-\mathrm{C}, \boldsymbol{N}, \boldsymbol{N}-\left[\mathrm{C}_{6} \mathrm{H}_{4} \mathrm{CH}=\mathrm{NB}(\right.\right.$ cat $\left.\left.) \mathrm{N}=\mathrm{CHPh}\right]\right\}\left(\mathrm{P}^{\mathrm{i}} \mathrm{Pr}_{3}\right)_{2}$ (2). Benzonitrile $(103 \mu \mathrm{L}, 1.0 \mathrm{mmol})$ and catecholborane $(214 \mu \mathrm{L}, 2.0$ mmol) were added to a solution of $1(100 \mathrm{mg}, 0.2 \mathrm{mmol})$ in $2 \mathrm{~mL}$ of toluene. The resulting solution was heated at $50^{\circ} \mathrm{C}$ for $6 \mathrm{~h}$. The reaction crude was concentrated to dryness under reduced pressure obtaining an orange oil. The addition of pentane at $-78^{\circ} \mathrm{C}$ afforded an orange solid which was washed with pentane $(2 \times 1 \mathrm{~mL})$ and dried in vacuo. Yield: $63 \mathrm{mg}(38 \%)$ The low isolated yield is due to the high solubility of complex 2 in the usual organic solvents. NMR data showed the presence of two isomers in an 85:15 molar ratio. Orange single crystals of the major isomer 2a suitable for $\mathrm{X}$-ray diffraction analysis were grown from a solution of 2 in pentane at -30 ${ }^{\circ} \mathrm{C}$. NMR. Anal. Calcd for $\mathrm{C}_{38} \mathrm{H}_{59} \mathrm{BN}_{2} \mathrm{O}_{2} \mathrm{OsP}_{2}$ : C, 54.41; H, 7.09; N, 3.34 . Found: C, 54.69; H, 6.94; N, 3.22. HR-MS (electrospray): $\mathrm{m} / \mathrm{z}$ calcd for $\mathrm{C}_{38} \mathrm{H}_{59} \mathrm{BN}_{2} \mathrm{O}_{2} \mathrm{OsP}_{2}[\mathrm{M}]^{+}$840.3754; found 840.3731. ${ }^{1} \mathrm{H}$ NMR (300.13 $\left.\mathrm{MHz}, \mathrm{C}_{6} \mathrm{D}_{6}, 298 \mathrm{~K}\right): \delta 9.40(\mathrm{br}, 1 \mathrm{H}, \mathrm{NCH}), 8.98(\mathrm{br}, 1 \mathrm{H}, \mathrm{NCH}), 8.13(\mathrm{~d}$, $\left.{ }^{3} J_{\mathrm{H}-\mathrm{H}}=7.8,2 \mathrm{H}, \mathrm{CH} \mathrm{Ph}\right), 8.04\left(\mathrm{~d},{ }^{3} \mathrm{H}_{\mathrm{H}-\mathrm{H}}=7.6,1 \mathrm{H}, \mathrm{CH} \mathrm{Ph}\right), 7.46(\mathrm{~m}, 1 \mathrm{H}, \mathrm{CH}$ $\mathrm{Ph}), 7.32$ (m, 2H, Bcat), 7.20 (m, 2H, CH Ph), 7.12 (m, 2H, CH Ph), 7.05 (m, 2H, Bcat), 6.97 (m, 1H, CH Ph), 2.10 (m, 6H, CH $\left.{ }^{\mathrm{i}} \mathrm{Pr}\right), 1.13$ (dvt, ${ }^{3} \mathrm{H}-\mathrm{H}$ $\left.=6.8, N=12.7,18 \mathrm{H}, \mathrm{CH}_{3}{ }^{\mathrm{i}} \mathrm{Pr}\right), 1.04\left(\mathrm{dvt},{ }^{3} \mathrm{H}_{\mathrm{H}-\mathrm{H}}=6.9, N=12.9,18 \mathrm{H}, \mathrm{CH}_{3}\right.$ $\left.{ }^{i} \mathrm{Pr}\right),-4.44\left(\mathrm{dt},{ }^{2}{ }_{\mathrm{H}-\mathrm{H}}=20.8,{ }^{2}{ }_{\mathrm{H}-\mathrm{P}}=13.1,1 \mathrm{H}, \mathrm{OsH}\right),-7.55\left(\mathrm{dt},{ }^{2} \mathrm{H}_{\mathrm{H}-\mathrm{H}}=20.8\right.$, $\left.{ }^{2} J_{\mathrm{H}-\mathrm{P}}=14.4,1 \mathrm{H}, \mathrm{OsH}\right) .{ }^{31} \mathrm{P}\left\{{ }^{1} \mathrm{H}\right\} \mathrm{NMR}\left(121.4 \mathrm{MHz}, \mathrm{C}_{7} \mathrm{D}_{8}, 298 \mathrm{~K}\right): \delta 6.4(\mathrm{~s})$. ${ }^{11} \mathrm{~B}$ NMR (128.38 MHz, $\left.\mathrm{C}_{7} \mathrm{D}_{8}, 298 \mathrm{~K}\right): \delta 14.7(\mathrm{br}) .{ }^{13} \mathrm{C}\left\{{ }^{1} \mathrm{H}\right\}$ APT NMR $\left(75.48 \mathrm{MHz}, \mathrm{C}_{7} \mathrm{D}_{8}, 298 \mathrm{~K}\right): \delta 171.4(\mathrm{~s}, \mathrm{CH} \mathrm{Ph}), 164.0\left(\mathrm{t},{ }^{2} \mathrm{C}-\mathrm{p}=6.0, \mathrm{Os}-\mathrm{C}\right)$, 163.4, 162.0 (both s, NCH), 153.6, 152.8 (both s, $\mathrm{C}_{\mathrm{q}} \mathrm{Ph}$ ), 145.3, 144.7 (both CH Ph), 136.6 (C $\mathrm{C}_{\mathrm{q}}$ Bcat), 130.3, 129.2, 127.7, 120.5, (all CH Ph), 119.0, 109.4 (both s, CH Bcat), 26.1 (vt, $N=24.4, \mathrm{CH}{ }^{\mathrm{i}} \mathrm{Pr}$ ), 19.9, 19.7 (both s, $\mathrm{CH}_{3}{ }^{\mathrm{i}} \mathrm{Pr}$ ).

\section{Preparation of $\mathrm{OsH}_{2}\left\{\boldsymbol{x}^{3}-\mathrm{C}, \mathbf{N}, \mathbf{N}\right.$ -} $\left.\left[\mathrm{C}_{6} \mathrm{H}_{3} \mathrm{MeCH}=\mathrm{NB}(\mathrm{cat}) \mathrm{N}=\mathrm{CHC}_{6} \mathrm{H}_{4} \mathrm{Me}\right]\right\}\left(\mathrm{PiPr}_{3}\right)_{2}$ (3). o-Tolunitrile $(30$ $\mu \mathrm{L}, 0.25 \mathrm{mmol})$ and catecholborane $(53.5 \mu \mathrm{L}, 0.5 \mathrm{mmol})$ were added to a solution of $1(25 \mathrm{mg}, 0.05 \mathrm{mmol})$ in $2 \mathrm{~mL}$ of toluene. The resulting solution was heated at $50^{\circ} \mathrm{C}$ for $18 \mathrm{~h}$. The reaction crude was concentrated to dryness under reduced pressure obtaining an orange oil. A concentrated solution of the oil in pentane was kept at $-30^{\circ} \mathrm{C}$ for $18 \mathrm{~h}$ to give an orange solid which was dried in vacuo. Yield: $18 \mathrm{mg}$ (40\%). The low isolated yield is due to the high solubility of complex $\mathbf{3}$ in the usual organic solvents. Anal.
Calcd for $\mathrm{C}_{40} \mathrm{H}_{63} \mathrm{BN}_{2} \mathrm{O}_{2} \mathrm{OsP}_{2}$ : C, 55.42; H, 7.33; N, 3.23. Found: C, 55.03; $\mathrm{H}, 7.07$; N, 3.08. ${ }^{1} \mathrm{H}$ NMR $\left(300.13 \mathrm{MHz}, \mathrm{C}_{6} \mathrm{D}_{6}, 298 \mathrm{~K}\right): \delta 9.69(\mathrm{br}, 1 \mathrm{H}$, $\mathrm{NCH}$ ), 9.57 (br, $1 \mathrm{H}, \mathrm{NCH}), 9.28\left(\mathrm{~d},{ }^{3} \mathrm{H}_{\mathrm{H}-\mathrm{H}}=7.7,1 \mathrm{H}, \mathrm{CH} \mathrm{C} 6 \mathrm{H}_{3} \mathrm{Me}\right), 7.87$ $\left(\mathrm{d},{ }^{3} \mathrm{H}_{\mathrm{H}-\mathrm{H}}=7.7,1 \mathrm{H}, \mathrm{C}_{6} \mathrm{H}_{4} \mathrm{Me}\right.$ ), $7.34\left(\mathrm{~m}, 1 \mathrm{H}, \mathrm{C}_{6} \mathrm{H}_{3} \mathrm{Me}\right), 7.29$ (m, 2H, Bcat), $7.13\left(\mathrm{~m}, 2 \mathrm{H}, \mathrm{CH} \mathrm{C}_{6} \mathrm{H}_{4} \mathrm{Me}+\mathrm{C}_{6} \mathrm{H}_{3} \mathrm{Me}\right), 7.02(\mathrm{~m}, 2 \mathrm{H}, \mathrm{Bcat}), 6.92(\mathrm{~m}, 1 \mathrm{H}$, $\left.\mathrm{C}_{6} \mathrm{H}_{4} \mathrm{Me}\right), 6.76\left(\mathrm{~m}, 1 \mathrm{H}, \mathrm{C}_{6} \mathrm{H}_{4} \mathrm{Me}\right), 2.34(\mathrm{~s}, 3 \mathrm{H}, \mathrm{Me}), 2.15$ (m, 6H, CH $\left.{ }^{\mathrm{i}} \mathrm{Pr}\right)$, 2.08 (s, 3H, Me), $1.17\left(\mathrm{dvt},{ }^{3}\right)_{\mathrm{H}-\mathrm{H}}=6.8, N=12.4,18 \mathrm{H}, \mathrm{CH}_{3}{ }^{\mathrm{i}} \mathrm{Pr}$ ), 1.04 (dvt, $\left.{ }^{3} J_{\mathrm{H}-\mathrm{H}}=7.2, N=12.8,18 \mathrm{H}, \mathrm{CH}_{3}{ }^{\mathrm{i}} \mathrm{Pr}\right),-4.29\left(\mathrm{dt},{ }^{2} J_{\mathrm{H} \cdot \mathrm{H}}=22.5,{ }^{2} J_{\mathrm{H}-\mathrm{P}}=14.5,1 \mathrm{H}\right.$, $\mathrm{OsH}),-7.55\left(\mathrm{dt},{ }^{2}{ }_{\mathrm{H}-\mathrm{H}}=22.5,{ }^{2} \mathrm{H}_{\mathrm{H}-\mathrm{P}}=14.7,1 \mathrm{H}, \mathrm{OsH}\right) .{ }^{31} \mathrm{P}\left\{{ }^{1} \mathrm{H}\right\} \mathrm{NMR}(121.4$ $\left.\mathrm{MHz}, \mathrm{C}_{6} \mathrm{D}_{6}, 298 \mathrm{~K}\right): \delta 6.3$ (s). ${ }^{11} \mathrm{~B}$ NMR $\left(128.38 \mathrm{MHz}, \mathrm{C}_{6} \mathrm{D}_{6}, 298 \mathrm{~K}\right): \delta$ 14.9 (br) ${ }^{13} \mathrm{C}\left\{{ }^{1} \mathrm{H}\right\}$ APT NMR $\left(75.48 \mathrm{MHz}, \mathrm{C}_{6} \mathrm{D}_{6}, 298 \mathrm{~K}\right): \delta 165\left(\mathrm{t},{ }^{2} J_{\mathrm{C}-\mathrm{P}}=\right.$ 6.0, Os-C), 160.0, 159.7 (both s, NCH), 153.5 (s, $\mathrm{C}_{\mathrm{q}} \mathrm{Ar}$ ), 142.5 (s, CH Ar), 139.9, 137.2 (both s, $\mathrm{C}_{q} \mathrm{Ar}$ ), 134.7 (s, $\mathrm{C}_{\mathrm{q}}$ Bcat), 130.7, 130.0, 129.0, 127.1, 124.7, 122.0 (all s, CH Ar), 119.0, 109.4 (both s, CH Bcat), 25.8 (vt, $N=$ 24.6, $\mathrm{CH}^{\mathrm{i}} \mathrm{Pr}$ ), 20.0, 19.6 (both s, $\mathrm{CH}_{3}{ }^{\mathrm{i}} \mathrm{Pr}$ ), 18.8, 18.3 (both s, Me).

Reaction of $\mathrm{OsH}_{3}\left\{\boldsymbol{\kappa}^{2}-H, H-\left(\mathrm{H}_{2} \mathrm{Bcat}\right)\right\}\left(\mathrm{P}^{\mathrm{i}} \mathrm{Pr}_{3}\right)_{2}$ (4) with Benzonitrile: Formation of $\left.\mathrm{OsH}_{3}\left\{\boldsymbol{x}^{2}-H, N-[\mathrm{HB}(\mathrm{cat}) \mathrm{N}=\mathrm{CHPh})\right]\right\}\left(\mathrm{P}^{\prime} \mathrm{Pr}_{3}\right)_{2}$ (6). Catecholborane $(5.4 \mu \mathrm{L}, 0.05 \mathrm{mmol})$ was added to an NMR tube containing a solution of 1 ( $25 \mathrm{mg}, 0.05 \mathrm{mmol})$ in $0.5 \mathrm{~mL}$ toluene- $d_{8}$. The tube was heated for $18 \mathrm{~h}$ at $50{ }^{\circ} \mathrm{C}$ obtaining a mixture of 4 and $\mathrm{OsH}\left(\eta^{3}-\mathrm{H}_{2} \mathrm{Bcat}\right)\left(\eta^{2}-\right.$ HBcat $)\left(\mathrm{P}^{\mathrm{P}} \mathrm{Pr}_{3}\right)_{2}$ in a 90:10 molar ratio. ${ }^{16}$ After this time, the NMR tube was cooled to $-78^{\circ} \mathrm{C}$ and benzonitrile $(25.8 \mu \mathrm{L}, 0.25 \mathrm{mmol})$ was added observing the immediate and quantitative transformation of 4 into $6 .{ }^{1} \mathrm{H}$ NMR $\left(400.13 \mathrm{MHz}, \mathrm{C}_{7} \mathrm{D}_{8}, 243 \mathrm{~K}\right): \delta 9.08(\mathrm{~s}, 1 \mathrm{H}, \mathrm{NCH}), 8.37(\mathrm{~m}, 2 \mathrm{H}, o-\mathrm{CH}$ $\mathrm{Ph}), 7.26(\mathrm{~m}, 2 \mathrm{H}, m-\mathrm{CH} \mathrm{Ph}), 7.15$ (m, 2H, Bcat), $7.22(\mathrm{~m}, 1 \mathrm{H}, p-\mathrm{CH} \mathrm{Ph})$, 6.96 (m, 2H, Bcat), 2.23 (m, 6H, CH $\left.{ }^{\mathrm{i}} \mathrm{Pr}\right), 1.28\left(\mathrm{dvt},{ }^{3} \mathrm{H}_{\mathrm{H}-\mathrm{H}}=6.8, N=13.4\right.$, $18 \mathrm{H}, \mathrm{CH}_{3}{ }^{\mathrm{i}} \mathrm{Pr}$ ), 1.09 (dvt, $\left.{ }^{3}{ }_{\mathrm{H}-\mathrm{H}}=6.6, N=12.6,18 \mathrm{H}, \mathrm{CH}_{3}{ }^{i} \mathrm{Pr}\right),-5.06(\mathrm{br}$, $1 \mathrm{H}, \mathrm{OsHB}),-9.88\left(\mathrm{br}, 2 \mathrm{H}, \mathrm{OsH}_{2}\right),-10.79(\mathrm{br}, 1 \mathrm{H}, \mathrm{OsH}) .{ }^{1} \mathrm{H}$ NMR $(400.13$ $\left.\mathrm{MHz}_{7} \mathrm{C}_{7} \mathrm{D}_{8}, 183 \mathrm{~K}\right): \delta 9.89(\mathrm{~s}, 1 \mathrm{H}, o-\mathrm{CH} \mathrm{Ph}), 9.09(\mathrm{~s}, 1 \mathrm{H}, 1 \mathrm{H}, \mathrm{NCH}), 7.41$ (br, 2H, m-CH Ph), 7.25 (m, 2H, Bcat), 7.13 (br, 1H, $p-\mathrm{CH} \mathrm{Ph),} 6.95$ (m, $2 \mathrm{H}, \mathrm{Bcat}$ ), 6.73 (s, $1 \mathrm{H}, o$-CH Ph), 2.16 (br, $\left.6 \mathrm{H}, \mathrm{CH}{ }^{\mathrm{i}} \mathrm{Pr}\right), 1.29$ (br, $18 \mathrm{H}$, $\left.\mathrm{CH}_{3}{ }^{\mathrm{i}} \mathrm{Pr}\right), 1.01$ (br, $18 \mathrm{H}, \mathrm{CH}_{3}{ }^{\mathrm{i}} \mathrm{Pr}$ ), -4.97 (br, $\left.1 \mathrm{H}, \mathrm{OsHB}\right),-8.86,-10.62$, 10.80 (all br, $1 \mathrm{H}$ each, $\left.\mathrm{OsH}_{3}\right) .{ }^{31} \mathrm{P}\left\{{ }^{1} \mathrm{H}\right\} \mathrm{NMR}\left(121.4 \mathrm{MHz}, \mathrm{C}_{7} \mathrm{D}_{8}, 243 \mathrm{~K}\right): \delta$ 30.5 (s). ${ }^{11} \mathrm{~B}$ NMR $\left(128.38 \mathrm{MHz}, \mathrm{C}_{7} \mathrm{D}_{8}, 243 \mathrm{~K}\right): \delta-6.7$ (br).${ }^{13} \mathrm{C}\left\{{ }^{1} \mathrm{H}\right\}$ APT NMR (75.48 MHz, $\left.\mathrm{C}_{7} \mathrm{D}_{8}, 243 \mathrm{~K}\right): \delta 156.3(\mathrm{~s}, \mathrm{NCH}), 151.9$ (s, $\left.\mathrm{C}_{\mathrm{q}} \mathrm{Bcat}\right)$, 137.4 (s, $\mathrm{C}_{\mathrm{q}} \mathrm{Ph}$ ), 130.1 (s, $\left.o-\mathrm{CH} \mathrm{Ph}\right), 129.0$ (s, $p$-CH Ph), 128.1 (s, $m$-CH $\mathrm{Ph}$ ), 119.8, 110.2 (both s, CH Bcat), 27.1 (vt, $N=23.8, \mathrm{CH}^{\mathrm{i}} \mathrm{Pr}$ ), 20.5, 19.7 (both s, $\mathrm{CH}_{3}{ }^{\mathrm{P}} \mathrm{Pr}$ ).

Monitoring of the Reaction of 1 with Benzonitrile and Catecholborane by ${ }^{31} \mathrm{P}\left\{{ }^{1} \mathrm{H}\right\} \quad$ NMR Spectroscopy: Formation of $\mathrm{OsH}_{3}\left\{\kappa^{2}-H, H-\right.$ $\left(\mathrm{H}_{2} \mathrm{Bcat}\right)\left(\mathrm{P}^{\mathrm{i}} \mathrm{Pr}_{3}\right)_{2}(4), \mathrm{OsH}_{3}\left\{\kappa^{2}-H, N-[\mathrm{N}(=\mathrm{CHPh}) \mathrm{Bcat}(\mathrm{H})]\right\}\left(\mathrm{P}^{2} \mathrm{Pr}_{3}\right)_{2}$ (6), $\mathrm{OsH}_{3}\left\{\kappa^{2}-N, C\right.$ - $\left.\left[\mathrm{N}(\mathrm{Bcat})=\mathrm{CHC}_{6} \mathrm{H}_{4}\right]\right\}\left(\mathrm{P}^{\mathrm{i}} \mathrm{Pr}_{3}\right)_{2} \quad(7)$, and $\mathrm{OsH}_{2}\left\{\kappa^{3}-C, N, N-\right.$ $\left.\left[\mathrm{C}_{6} \mathrm{H}_{4} \mathrm{CH}=\mathrm{NB}(\mathrm{cat}) \mathrm{N}=\mathrm{CHPh}\right]\right\}\left(\mathrm{P}^{\mathrm{i}} \mathrm{Pr}_{3}\right)_{2}$ (2). An NMR tube was charged with catecholborane $(53.5 \mu \mathrm{L}, 0.5 \mathrm{mmol})$, benzonitrile $(25.8 \mu \mathrm{L}, 0.25$ $\mathrm{mmol})$ and $1(25 \mathrm{mg}, 0.05 \mathrm{mmol})$ and $0.5 \mathrm{~mL}$ of toluene- $d_{8}$. The mixture was heated at $50{ }^{\circ} \mathrm{C}$ during $4 \mathrm{~h}$ and the reaction was monitored by ${ }^{31} \mathrm{P}\left\{{ }^{1} \mathrm{H}\right\}$ NMR. The monitoring of these reactions by ${ }^{31} \mathrm{P}\left\{{ }^{1} \mathrm{H}\right\}$ NMR (Figure 4) showed the formation of complexes $2,4,6$, and 7 .

\section{ASSOCIATED CONTENT}

Supporting Information. The Supporting Information is available free of charge on the ACS Publications website General Information, NMR spectra, structural analysis, and computational details (PDF)

Cartesian coordinates of all molecules, intermediates, and transition states (XYZ) 


\section{Accession Codes}

CCDC 2039358 contains the supplementary crystallographic data for this paper. These data can be obtained free of charge via www.ccdc.cam.ac.uk/data_request/cif, or by emailing data_request@ccdc.cam.ac.uk, or by contacting The Cambridge Crystallographic Data Centre, 12 Union Road, Cambridge CB2 1EZ, UK; fax: +441223336033.

\section{AUTHOR INFORMATION}

\section{Corresponding Author}

*E-mail: maester@unizar.es.

Notes

The authors declare no competing financial interest.

\section{ACKNOWLEDGMENT}

Financial support from the MINECO of Spain (Projects CTQ201782935-P (AEI/FEDER, UE), CTQ2016-78205-P, PID2019106184GB-I00, and RED2018-102387-T), Gobierno de Aragón (Group E06_20R and project LMP148_18), FEDER, and the European Social Fund is acknowledged.

\section{REFERENCES}

(1) Pincer Compounds: Chemistry and Applications, 1st ed.; Morales Morales, D., Ed.; Elsevier: Amsterdam, 2018.

(2) (a) Albrecht, M.; Van Koten, G. Platinum Group Organometallics Based on "Pincer" Complexes: Sensors, Switches, and Catalysts. Angew. Chem., Int. Ed. 2001, 3750-3781. (b) Choi, J.; MacArthur, A. H. R.; Brookhart, M.; Goldman, A. S. Dehydrogenation and Related Reactions Catalyzed by Iridium Pincer Complexes. Chem. Rev. 2011, 111, 17611779. (c) Gunanathan, C.; Milstein, D. Bond Activation and Catalysis by Ruthenium Pincer Complexes. Chem. Rev. 2014, 114, 12024-12087.

(3) (a) Albrecht, M.; Rodríguez, G.; Schoenmaker, J.; Van Koten, G. New Peptide Labels Containing Covalently Bonded Platinum(II) Centers as Diagnostic Biomarkers and Biosensors. Org. Lett. 2000, 2, 3461-3464. (b) Ni, W. X.; Man, W. L.; Cheung, M. T. W.; Sun, R. W. Y.; Shu, Y. L.; Lam, Y. W.; Che, C. M.; Lau, T. C. Osmium(VI) Complexes as a new class of potential anti-cancer agents. Chem. Commun. 2011, 47, 2140-2142. (c) Boff, B.; Gaiddon, C.; Pfeffer, M. Cancer Cell Cytotoxicity of Cyclometalated Compounds Obtained with Osmium(II) Complexes. Inorg. Chem. 2013, 52, 2705-2715. (d) Menéndez-Pedregal, E.; Manteca, Á.; Sánchez, J.; Díez, J.; Gamasa, M. P.; Lastra, E. Antimicrobial and Antitumor Activity of Enantiopure Pybox-Osmium Complexes. Eur. J. Inorg. Chem. 2015, 2015, 1424-1432.

(4) (a) Williams, J. A. G.; Wilkinson, A. J.; Whittle, V. L. Light-emitting iridium complexes with tridentate ligands. Dalton Trans. 2008, 2081-2099. (b) Chi, Y.; Chang, T.-K.; Ganesan, P.; Rajakannu, P. Emissive bistridentate $\mathrm{Ir}(\mathrm{III})$ metal complexes: Tactics, photophysics and applications. Coord. Chem. Rev. 2017, 346, 91-100.

(5) See for example: (a) Esteruelas, M. A.; Oliván, M.; Vélez, A. Conclusive Evidence on the Mechanism of the Rhodium-Mediated Decyanative Borylation. J. Am. Chem. Soc. 2015, 137, 12321-12329. (b) Esteruelas, M. A.; García-Yebra, C.; Martín, J.; Oñate, E. Dehydrogenation of Formic Acid Promoted by a Trihydride-Hydroxo-Osmium(IV) Complex: Kinetics and Mechanism. ACS Catal. 2018, 8, 11314-11323. (c) Sen, R.; Goeppert, A.; Kar, S.; Prakash, G. K. S. Hydroxide Based Integrated $\mathrm{CO}_{2}$ Capture from Air and Conversion to Methanol. J. Am. Chem. Soc. 2020, 142, 4544-
4549. (d) Tang, S.; Ben-David, Y.; Milstein, D. Oxidation of Alkenes by Water with H2 Liberation. J. Am. Chem. Soc. 2020, 142, 5980-5984. (e) Kumar, A.; von Wolff, N.; Rauch, M.; Zou, Y.-Q.; Shmul, G.; Ben-David, Y.; Leitus, G.; Avram, L.; Milstein, D. Hydrogenative Depolymerization of Nylons. J. Am. Chem. Soc. 2020, 142, 14267-14275. (f) Esteruelas, M. A.; Martínez, A.; Oliván, M.; Oñate, E. Direct C-H Borylation of Arenes Catalyzed by Saturated Hydride-Boryl-Iridium-POP Complexes: Kinetic Analysis of the Elemental Steps. Chem. - Eur.J. 2020, 26, 12632-12644.

(6) See for example: (a) Alabau, R. G.; Eguillor, B.; Esler, J.; Esteruelas, M. A.; Oliván, M.; Oñate, E.; Tsai, J.-Y.; Xia, C. CCC-Pincer-NHC Osmium Complexes: New Types of Blue-Green Emissive Neutral Compounds for Organic Light-Emitting Devices (OLEDs). Organometallics 2014, 33, 5582-5596. (b) Hsu, L.-Y.; Liang, Q.; Wang, Z.; Kuo, H.-H.; Tai, W.-S.; Su, S.-J.; Zhou, X.; Yuan, Y.; Chi, Y. Bis-Tridentate Ir ${ }^{\text {III }}$ Phosphors Bearing Two Fused Five-Six-Membered Metallacycles: A Strategy to Improved Photostability of Blue Emitters. Chem. - Eur.J. 2019, 25, 15375-15386. (c) Gnanasekaran, P.; Yuan, Y.; Lee, C.-S.; Zhou, X.; Jen, A. K.-Y.; Chi, Y. Realization of Highly Efficient Red Phosphorescence from Bis-Tridentate Iridium(III) Phosphors. Inorg. Chem. 2019, 58, 10944-10954. (d) Adamovich, V.; Boudreault, P.-L. T.; Esteruelas, M. A.; Gómez-Bautista, D.; López, A. M.; Oñate, E.; Tsai, J.Y. Preparation via a NHC Dimer Complex, Photophysical Properties, and Device Performance of Heteroleptic Bis(Tridentate) Iridium(III) Emitters. Organometallics 2019, $38,2738-2747$.

(7) Esteruelas, M. A.; Fernández, I.; Martínez, A.; Oliván, M.; Oñate, E.; Vélez, A. Iridium-Promoted B-B Bond Activation: Preparation and X-Ray Diffraction Analysis of a Mer -Tris(Boryl) Complex. Inorg. Chem. 2019, 58, 4712-4717.

(8) Zhu, Q.; Lin, L.; Qiu, R.; Zhu, J. Are Hetero-metallapentalenes Aromatic or Not? A DFT Investigation. Chem. - Eur.J.2020, 26, 5381-5387.

(9) Zhu, C.; Xia, H. Carbolong Chemistry: A Story of Carbon Chain Ligands and Transition Metals. Acc. Chem. Res. 2018, 51, 1691-1700.

(10) (a) Alós, J.; Bolaño, T.; Esteruelas, M. A.; Oliván, M.; Oñate, E.; Valencia, M. POP-Pincer Osmium-Polyhydrides: Head-to-Head (Z)Dimerization of Terminal Alkynes. Inorg. Chem. 2013, 52, 6199-6213. (b) Shao, J.-Y.; Zhong, Y.-W. Monometallic Osmium(II) Complexes with Bis( N-Methylbenzimidazolyl)Benzene or -pyridine: A Comparison Study with Ruthenium(II) Analogues. Inorg. Chem. 2013, 52, 6464-6472. (c) Chung, L.-H.; Cho, K.-S.; England, J.; Chan, S.-C.; Wieghardt, K.; Wong, C.-Y. Ruthenium(II) and Osmium(II) Complexes Bearing Bipyridine and the N-Heterocyclic Carbene-Based $\mathrm{C}^{\wedge} \mathrm{N}^{\wedge} \mathrm{C}$ Pincer Ligand: An Experimental and Density Functional Theory Study. Inorg. Chem. 2013, 52, 9885-9896. (d) Spasyuk, D.; Vicent, C.; Gusev, D. G. Chemoselective Hydrogenation of Carbonyl Compounds and Acceptorless Dehydrogenative Coupling of Alcohols. J. Am. Chem. Soc. 2015, 137, 3743-3746. (e) Alós, J.; Esteruelas, M. A.; Oliván, M.; Oñate, E.; Puylaert, P. C-H Bond Activation Reactions in Ketones and Aldehydes Promoted by POP-Pincer Osmium and Ruthenium Complexes. Organometallics 2015, 34, 4908-4921. (f) Shen, J.J.; Shao, J.-Y.; Gong, Z.-L.; Zhong, Y.-W. Cyclometalated Osmium-Amine Electronic Communication through the p-Oligophenylene Wire. Inorg. Chem. 2015, 54, 10776-10784. (g)Esteruelas, M. A.; García-Yebra, C.; Martín, J.; Oñate, E. Mer, Fac, and Bidentate Coordination of an Alkyl-POP Ligand in the Chemistry of Nonclassical Osmium Hydrides. Inorg. Chem. 2017, 56, 676-683. (h) Esteruelas, M. A.; Fernández, I.; García-Yebra, C.; Martín, J.; Oñate, E. 
Elongated $\sigma$-Borane versus $\sigma$-Borane in Pincer-POP-Osmium Complexes. Organometallics 2017, 36, 2298-2307 (i) Antiñolo, A.; Esteruelas, M. A.; García-Yebra, C.; Martín, J.; Oñate, E.; Ramos, A. Reactions of an Osmium(IV)-Hydroxo Complex with Amino-Boranes: Formation of Boroxide Derivatives. Organometallics 2019, 38, 310-318. (j) Esteruelas, M. A.; Fernández, I.; García-Yebra, C.; Martín, J.; Oñate, E. Cycloosmathioborane Compounds: Other Manifestations of the Hückel Aromaticity. Inorg. Chem. 2019, 58, 2265-2269.

(11) (a) Wen, T. Bin; Zhou, Z. Y.; Jia, G. Osmium-Mediated Hexamerization of Phenylacetylene. Angew. Chem., Int. Ed. 2006, 45, 5842-5846. (b) Kuznetsov, V. F.; Gusev, D. G. Chiral Hydride and Dihydrogen Pincer-Type Complexes of Osmium. Organometallics 2007, 26, 5661-5666. (c) Tsvetkov, N.; Fan, H.; Caulton, K. G. An Evaluation of Monovalent Osmium Supported by the PNP Ligand Environment. Dalton Trans. 2011, 40, 1105-1110. (d) Gruver, B. C.; Adams, J. J.; Arulsamy, N.; Roddick, D. M. Acceptor Pincer Chemistry of Osmium: Catalytic Alkane Dehydrogenation by $\left({ }^{\mathrm{CF} 3} \mathrm{PCP}\right) \mathrm{Os}(\mathrm{cod})(\mathrm{H})$. Organometallics 2013, 32, 6468-6475. (e) Chelucci, G.; Baldino, S.; Baratta, W. Recent Advances in Osmium-Catalyzed Hydrogenation and Dehydrogenation Reactions. Acc. Chem. Res. 2015, 48, 363-379. (f) Alabau, R. G.; Esteruelas, M. A.; Oliván, M.; Oñate, E.; Palacios, A. U.; Tsai, J.-Y.; Xia, C. Osmium(II) Complexes Containing a Dianionic CCCC-Donor Tetradentate Ligand. Organometallics 2016, 35, 3981-3995.

(12) Casarrubios, L.; Esteruelas, M. A.; Larramona, C.; Muntaner, J. G.; Oñate, E.; Sierra, M. A. 2-Azetidinones as Precursors of Pincer Ligands: Preparation, Structure, and Spectroscopic Properties of $\mathrm{CC}^{\prime} \mathrm{N}-\mathrm{O}$ smium Complexes. Inorg. Chem. 2015, 54, 10998-11006.

(13) (a) Li, Z.-Y.; Yu, W.-Y.; Che, C.-M.; Poon, C.-K.; Wang, R.-J.; Mak, T. C. W. Oxo-, Nitrido- and Imido-Osmium(VI) Complexes with a Sterically Bulky Chelating Alkoxide Ligand. J. Chem. Soc. Dalton Trans. 1992, 16571661. (b) Xiang, J.; Man, W.-L.; Yiu, S.-M.; Peng, S.-M.; Lau, T.-C. Reaction of an Osmium(VI) Nitrido Complex with Cyanide: Formation and Reactivity of an Osmium(III) Hydrogen Cyanamide Complex. Chem. - Eur. J.2011, 17, 13044-13051.

(14) Eguillor, B.; Esteruelas, M. A.; Lezáun, V.; Oliván, M.; Oñate, E.; Tsai, J.-Y.; Xia, C. A Capped Octahedral $\mathrm{MHC}_{6}$ Compound of a Platinum Group Metal. Chem. - Eur.J. 2016, 22, 9106-9110.

(15) (a) Eguillor, B.; Esteruelas, M. A.; Lezáun, V.; Oliván, M.; Oñate, E. Elongated Dihydrogen versus Compressed Dihydride in Osmium Complexes. Chem. - Eur. J. 2017, 23, 1526-1530. (b) Alabau, R. G.; Esteruelas, M. A.; Oliván, M.; Oñate, E. Preparation of Phosphorescent Osmium(IV) Complexes with N,N',C- and C,N,C'-Pincer Ligands. Organometallics 2017, 36, 1848-1859. (c) Cancela, L.; Esteruelas, M. A.; López, A. M.; Oliván, M.; Oñate, E.; San-Torcuato, A.; Vélez, A. OsmiumAnd Iridium-Promoted C-H Bond Activation of 2,2'-Bipyridines and Related Heterocycles: Kinetic and Thermodynamic Preferences. Organometallics 2020, 39, 2102-2115.

(16) Babón, J. C.; Esteruelas, M. A.; Fernández, I.; López, A. M.; Onate, E. Evidence for a Bis(Elongated $\sigma$ )-Dihydrideborate Coordinated to Osmium. Inorg. Chem. 2018, 57, 4482-4491.

(17) (a) Babón, J. C.; Esteruelas, M. A.; Fernández, I.; López, A. M.; Oñate, E. Redox-Assisted Osmium-Promoted C-C Bond Activation of Alkylnitriles. Organometallics 2018, 37, 2014-2017. (b) Babón, J. C.; Esteruelas, M. A.; Fernández, I.; López, A. M.; Oñate, E. Reduction of
Benzonitriles via Osmium-Azavinylidene Intermediates Bearing Nucleophilic and Electrophilic Centers. Inorg. Chem. 2019, 58, 86738684. (c) Babón, J. C.; Esteruelas, M. A.; López, A. M.; Oñate, E. OsmiumPromoted Transformation of Alkyl Nitriles to Secondary Aliphatic Amines: Scope and Mechanism. Organometallics 2020, 39, 2177-2188.

(18) Esteruelas, M. A.; López, A. M.; Oliván, M. Polyhydrides of Platinum Group Metals: Nonclassical Interactions and $\sigma$-Bond Activation Reactions. Chem. Rev. 2016, 116, 8770-8847.

(19) Babón, J. C.; Esteruelas, M. A.; Fernández, I.; López, A. M.; Oñate, E. Dihydroboration of Alkyl Nitriles Catalyzed by an Osmium-Polyhydride: Scope, Kinetics, and Mechanism. Organometallics 2020, 39, 3864-3872.

(20 ) Castro-Rodrigo, R.; Esteruelas, M. A.; Gómez-Bautista, D.; Lezáun, V.; López, A. M.; Oliván, M.; Oñate, E. Influence of the Bite Angle of Dianionic C,N,C-Pincer Ligands on the Chemical and Photophysical Properties of Iridium(III) and Osmium(IV) Hydride Complexes. Organometallics 2019, 38, 3707-3718.

(21) Braunschweig, H.; Fernández, I.; Frenking, G.; Radacki, K.; Seeler, F. Synthesis and Electronic Structure of a Ferroborirene. Angew. Chem., Int. Ed. 2007, 46, 5215-5218, and references therein.

(22) Outeiral, C.; Vincent, M. A.; Martín Pendás, Á.; Popelier, P. L. A. Revitalizing the concept of bond order through delocalization measures in real space. Chem. Sci. 2018, 9, 5517-5529.

(23) Esteruelas, M. A.; Fernández, I.; Herrera, A.; Martín-Ortiz, M.; Martínez-Álvarez, R.; Oliván, M.; Oñate, E.; Sierra, M. A.; Valencia, M. Multiple C-H Bond Activation of Phenyl-Substituted Pyrimidines and Triazines Promoted by an Osmium Polyhydride: Formation of Osmapolycycles with Three, Five, and Eight Fused Rings. Organometallics 2010, 29, 976-986.

(24) Srimani, D.; Diskin-Posner, Y.; Ben-David, Y.; Milstein, D. Iron Pincer Complex Catalyzed, Environmentally Benign, E-Selective SemiHydrogenation of Alkynes. Angew. Chem., Int. Ed. 2013, 52, 1413114134.

(25) Hillier, A. C.; Fox, T.; Schmalle, H. W.; Berke, H. Borohydride reduction of a rhenium-bound acetonitrile: an example of a chelating iminoborane ligand at a low valent metal center. J. Organomet. Chem. 2003, 669, 14-24.

(26) (a) Khalimon, A. Y.; Farha, P.; Kuzmin, L. G.; Nikonov, G. I. Catalytic hydroboration by an imido-hydrido complex of Mo(IV). Chem. Commun. 2012, 48, 455-457. (b) Khalimon, A. Y.; Farha, P. M.; Nikonov, G. I. Imido-hydrido complexes of $\mathrm{Mo}(\mathrm{IV})$ : catalysis and mechanistic aspects of hydroboration reactions. Dalton Trans., 2015, 44, 8945-18956.

(27) Esteruelas. M. A.; Oliván, M.; Vélez, A. Conclusive Evidence on the Mechanism of the Rhodium-Mediated Decyanative Borylation. J. Am. Chem. Soc. 2015, 137, 12321-12329.

(28) Aracama, M.; Esteruelas, M. A.; Lahoz, F. J.; López, J. A.; Meyer, U.; Oro, L. A.; Werner, H. Synthesis, Reactivity, Molecular Structure, and Catalytic Activity of the Novel Dichlorodihydridoosmium(IV) Complexes $\mathrm{OsH}_{2} \mathrm{Cl}_{2}\left(\mathrm{PR}_{3}\right)_{2} \quad\left(\mathrm{PR}_{3}=\mathrm{P}-i-\mathrm{Pr}_{3}, \mathrm{PMe}-t-\mathrm{Bu}_{2}\right)$. Inorg. Chem. 1991, 30, 288-293. 
TOC Graphic

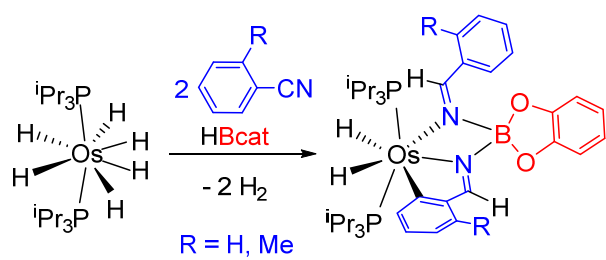

